\title{
Influence of inbreeding and some environmental factors on calving intervals in
} N'Dama cattle of Southwest Nigeria

Abanikannda, O. T. F. ${ }^{1}$ and Olutogun, O. ${ }^{2}$

${ }^{I}$ Department of Zoology and Environmental Biology, Lagos State University, Ojo - Lagos

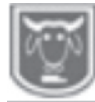
${ }^{2}$ Department of Animal Science, University of Ibadan, Ibadan, Nigeria Corresponding author: otfabanikannda@hotmail.com; +234 8023128376

\section{Abstract}

Records of 4184 N'Dama calves born between 1947 and 1984 at Fashola Stock Farm, Oyo State, Nigeria was used to compute inbreeding coefficient and determine its effects on calving intervals of cows. Only 273 of the 4184 calves (6.53\%) were inbred with an average inbreeding coefficient of $9.71 \%$, while five out of 293 sires had inbreeding coefficient of 9.25\% and 43 out of 1849 dams had inbreeding coefficient of 9.95\%. The inbreeding coefficient for the entire population was $0.63 \%$, respectively $0.70 \%$ and $0.58 \%$ for male and female calves. The average calving interval was $445.34 \pm 2.68$ days within the herd while year of birth, parity of dam, age of dam and dam's age at first calving all significantly $(P<0.05)$ impacted calving intervals of cows. Season of birth and inbreeding coefficient of dam did not exert statistical ( $P>0.05)$ influence on calving intervals of dams. Although the number of inbred animals in the population is relatively low, however the inbreeding level of these animals is high, which may be attributed to the fact that breeding policy on the farm was not strictly adhered to, and lack of proper and adequate registration system coupled with inconsistent animal identification system on the farm may be responsible for the inbreeding observed in the N'Dama population at Fashola Stock Farm.

Keywords: Inbreeding, N'Dama Cattle, Calving Interval, Nigeria

\section{Introduction}

Calving interval, the number of days a cow takes to conceive after the immediate last parturition is one of the most important criteria for determining reproductive ability of cow. This is influenced by lot of factors which include reproductive diseases, management practices, embryonic mortality, neonatal deaths and the presence of active fertile bulls (Olutogun, 1976). Calving interval like other performance traits of beef cattle are essentially traits of economic importance and are quantitative in characters, that is they are determined by several genes in differing genic combinations (Falconer, 1993), and it is worthy of note that the environment under which the animals are reared be considered while evaluating such traits. The extent to which these traits can be improved is basically determined by the innate ability of the individual animal. Thus, long range approach aimed at improving the animal's performance must be directed through improving the animal's genetic constitution. Inbreeding defined as the mating together of individuals that are related to each other by ancestry (Falconer, 1993), is the mating of animals more closely related than the average of the population from which they come. The major aim of inbreeding is to increase the probability that two alleles at a particular locus in an individual are identical by descent, and this will result in an increase in the proportion of homozygous loci in the inbred individual (Fisher, 1965 and Smith et al, 1998). The undesirable consequence of this increased homozygosity is a decline in performance of traits associated with general vigour such as reproduction, 


\section{Influence of inbreeding on calving intervals of N'Dama cattle}

survival and growth rates (Brinks and Knapp, 1975; Sachdeva et al. 1983; Guba and Wolf, 1984; Mac Neil et al. 1989, Mc Parland et al. 2007 and Musingi et al. 2018). Inbreeding increases uniformity for simply inherited and highly heritable traits but it also leads to increased variability for economically important quantitative traits (Hohenboken, 1985 and Cassell, 1999). Various researches on inbreeding indicated that inbreeding has not always had the same effect on productivity, but in most instances, productivity has declined with increasing levels of inbreeding (Noland et al, 1964, Mc Parland et al. 2007 and Musingi et al, 2018). The effect of inbreeding has been extensively investigated on cattle. Although the fact that these animals are uniparous with a relatively longer generation interval had been an impediment to the study of inbreeding effects on reproductive performance, however appreciable data has been collected on most of the productive traits of cattle. Some deleterious diseases of cattle had been linked with inbreeding (Baird et al, 1986; Havrankova et al, 1984) such as dilated cardiomyopathy and achondroplasia in the progeny of some bulls. Sorensen and Kennedy (1984) reported that in random mating populations of finite size, with an additive genetic model, the additive genetic variance declines with levels of inbreeding. Russell et al (1984) also reported that genetic variances change with increasing level of inbreeding. Inbreeding has been reported to be one of many factors affecting various reproductive indices either directly or indirectly. For example, the cystic ovarian disease of cows has been reported to be hereditary (Cole et al. 1986) and the incidence of the disease increases with increasing level of inbreeding. Flade and Zeller (1986) also reported that levels of inbreeding of bulls affect their age at first semen collection, semen production, sperm concentration, mass motility and forward motility. They reported that out of bulls that were $12.5 \%$ and $6.25 \%$ inbred, $50.2 \%$ and $39.8 \%$ respectively did not produce viable semen. These low performances resulting from inbreeding depression were significant when compared with their contemporaries that were non-inbred. Maksimova and Brovko (1985) also reported that level of inbreeding of cows affected the number of inseminations per conception. However, Kravchenko et al (1985) reported in their study that moderate inbreeding involving a single high producing ancestor did not have adverse effect on reproductive traits of cows. The shorter the interval between two successive calving, the better the reproductive ability of the cow. Inbreeding like several other factors has been reported to affect the calving interval of cattle. Maksimova and Brovko (1985) reported that the degree of inbreeding of cows significantly affect their average calving intervals. Hudson et al (1984) also reported that calving interval steadily increased with increasing level of inbreeding of cows. The Fashola Stock Farm was essentially set up as a breeding and improvement centre of N'Dama Cattle as far back as 1947. Consequently, the volume of records available can readily give an insight into the various environmental and genetic factors affecting the herd's productivity, albeit scanty and incomplete. Several breeding methods had been adopted on the farm at various times in the past and these available records are large enough to provide sufficient information on the merit and demerits of past efforts if appropriate tools (technical and statistical) are available to take care of the peculiarities of the data available. In order to circumvent the undesirable effects of inbreeding, some suggestions have been proffered to avoid inbreeding and improve livestock 


\section{Abanikannda and Olutogun}

productivity. It was suggested that in a situation where animal populations are small, there should be a rapid turnover of sires to minimise inbreeding (McDowell, 1983). Crossing of full-sib families having a common parent should be avoided and modified full-sib selection could be used alternately with half-sib selection or typical full-sib selection may be carried out once after several cycles of modified full-sib selection (Dhillon and Khehra, 1984). Due to the fact that the farm was not originally set up for inbreeding purposes and that importation of fresh genetic stock was stopped for a relatively long time on the farm, it can be expected that some inbreeding may have inadvertently occurred due to the inconsistent management systems adopted on the farm. To this end, this study aims at developing a computer program that can trace and retrieve all the pedigree information on all animals born on any farm whose immediate parents (sire and dam) are known, and chart the pedigree of such animals and estimate its inbreeding coefficient which is then used as a covariate along with other factors to study their effects on the Calving intervals of N'Dama cattle.

\section{Materials and methods Study site}

Data for this study were derived from the record books of Fashola Stock Farm which was founded in 1947 by the former British Colonial Government as multiplication centre for the distribution of N'Dama, Keteku and Muturu cattle breeds to local farmers. It also served as an experimental research farm to transfer research results to local farmers and a training ground for students and aspiring cattle farmers (Olutogun, 1976 and Abanikannda, 1995). The farm is geographically situated in a low-to-medium tsetse fly risk zone in the derived Guinea Savanna belt of Nigeria at an altitude of $228.6 \mathrm{~m}$ above sea level on latitude $7^{\circ} 54^{\prime} \mathrm{N}$ and longitude $3^{\circ} 43^{\prime} \mathrm{E}$ of the Equator. The climatic condition of Fashola stock farm is more of tropical rain forest than the derived savanna with its annual rainfall pattern influenced by two opposing winds viz. the southwest monsoon and the northeast trade winds resulting in two major seasons in a year viz.: the wet and dry seasons. These two broad seasons are further subdivided into four as follows: early wet (April - June), late wet (July September), early dry (October December) and late dry (January - March). The temperature in the farm range between $21^{\circ} \mathrm{C}$ and $33^{\circ} \mathrm{C}$, with relative humidity varying between $52 \%$ and $78 \%$ depending on the period of the year (Abanikannda, 1995). The 340 hectares of land on the farm was divided into 107 paddocks of about 2 hectares each and established with grasslegume mixtures. Maintenance of pasture included slashing, mowing and occasionally pastures invaded by weeds are burnt in the dry season and ploughed back into the soil. The farm is established on semi-intensive system of husbandry, where animals were grouped into paddocks according to their sex, age and physiological status. Essentially, breeding on the farm was by pasture mating, where a bull is allowed access to the breeding cows throughout the year in each fenced paddock. The Bull to Cow ratio for pasture mating fluctuates between 1:20 and 1:30. Heifers were first introduced to bulls between the ages of two and three years and nursing cows were reintroduced into the breeding paddocks at $45-60$ days postpartum. A veterinary unit attached to the farm carried out all necessary disease control measures and emergencies, and sick animals were kept in the sick bay and postmortem of dead animals was done to identify probable cause of death. Each animal on the farm were properly identified 


\section{Influence of inbreeding on calving intervals of N'Dama cattle}

and tagged and those born on the farm were so identified soon after birth by any of these methods; tattooing, neck-tag, ear notching or branding.

\section{Data collection and preparation}

Major records kept on the farm were those of calving, weight and mortality, kept in a series of field books and collected since the inception of the farm in 1947 up till 1984. Data used in this study were extracted from such records kept on the farm containing information about calf identification number, calf breed, date of birth, sex of calf, sire identification number, sire breed, dam identification number, dam breed, birth weight of calf, weaning weight of calf and age of calf at weaning. The extracted data were transcribed to the Dbase IV (1990) computer database management system prior to analyses.

The extracted data were used for preliminary exploratory descriptive analyses to verify and validate recorded data. Some variables not originally present in the field books were then computed, such as assigning animals to the different seasons. Calving interval was computed from the difference (days) of successive parturitions. After arranging all births chronologically and by dam, the parity and ages of dam whenever they calve were calculated.

Inbreeding coefficient of dam was calculated using the developed computer program (Abanikannda, 1995) to handle animals with minimal parental information by using the path searching and path coefficients of Wright (1921). Inbreeding coefficient is a measure of the degree of inbreeding and it is the correlation between uniting gametes. The first attempt at estimating inbreeding coefficient was made by Sewall Wright in 1921. Wright's classical path coefficient analysis of inbreeding systems provides an expression for the degree of homozygosity that occurs as a result of mating related animals. Malécot (1969) also describe the coefficient of inbreeding (F) as the correlation between the genic content of gametes which unite to produce the individual or the probability of the gametes being identical in origin, by descent from a common ancestor. Wright (1922) coefficient of inbreeding provide the quantitative basis for estimating consequences from any sort of inbreeding based on pedigree relationships, ignoring possible effects of selection and assortative mating. He developed a system of estimating inbreeding coefficient based on the formula;

$\mathrm{F}_{\mathrm{x}}=\Sigma(1 / 2)^{\mathrm{n}+\mathrm{n}^{\prime}+1}\left(1+\mathrm{F}_{\mathrm{a}}\right)$

where $F_{x}=$ the inbreeding coefficient of individual $\mathbf{x}$

$\mathrm{n}=$ the number of generations through the sire

$\mathrm{n}^{\prime}=$ the number of generations through the dam, and

$\mathrm{F}_{\mathrm{a}}=$ the inbreeding coefficient of a common ancestor a

The $F_{x}$ is the sum total of all possible paths of the ancestors common to both the sire and dam. And this can be computed with the knowledge of the pedigree of the individual $\mathbf{x}$. This inbreeding coefficient of an individual is one half the numerator of the relationship coefficient between its sire and dam.

\section{Statistical analysis}

The validated data were analyzed using the General Linear Model Procedure of SAS (1999). Year of birth, season of birth and parity of dam were used as fixed effects, while age of dam, age at first calving and inbreeding of the dam were used as covariates in the statistical analysis. The general model describing calving interval of N'Dama cows was:

$\mathrm{Y}_{\mathrm{ij} k \mathrm{lmno}}=\mu+\mathrm{Y}_{\mathrm{i}}+\mathrm{S}_{\mathrm{j}}+\mathrm{P}_{\mathrm{k}}+\mathrm{D}_{\mathrm{l}}+\mathrm{C}_{\mathrm{m}}+\mathrm{B}_{\mathrm{n}}+$ $\mathrm{e}_{\mathrm{ijk} l m n o}$

Where $\mathrm{Y}_{\mathrm{ijklmno}}=\quad$ Individual cow's 


\section{Abanikannda and Olutogun}

calving interval

$\begin{array}{ll}\mu & =\text { Population mean } \\ \mathrm{Y}_{\mathrm{i}} & =\text { Year of birth }(\mathrm{i}=1,2, \ldots \ldots 31) \\ \mathrm{S}_{\mathrm{j}} & =\text { Season of birth }(\mathrm{j}=1,2, \ldots 4) \\ \mathrm{P}_{\mathrm{k}} & =\text { Parity of dam }(\mathrm{k}=1,2, \ldots 8) \\ \mathrm{D}_{1} & =\text { Regression of age of dam } \\ \mathrm{C}_{\mathrm{m}} & =\text { Regression of age at first } \\ & \text { calving of dam } \\ \mathrm{B}_{\mathrm{n}} & =\text { Regression of inbreeding } \\ & \text { coefficient of dam } \\ \mathrm{e}_{\mathrm{ijklmno}} & =\text { Residual random error }\end{array}$

\section{Results and discussion}

The period of time between two successive parturitions in the cattle is known as the calving interval and the shorter the calving interval the more the number of calving of the cow during its productive years. The mean calving interval (CALINT) for 1270 cows used in this study was $445.34 \pm 2.68$ days with a coefficient of variation of 21.41 percent. This is equivalent to an average calving rate of 81.96 percent (Table 1).

The year of birth of cows, parity of dam, age of dam and its age at first calving significantly $(\mathrm{P}<0.05)$ influenced its average calving interval. However, season of birth and dam's inbreeding coefficient did not exert significant $(\mathrm{P}>0.05)$ impact on calving interval. Factors reported to affect the calving intervals of N'Dama are age of cow, parity, year and season of calving and age at first calving (Olutogun, 1976; Tizikara, 1988; Fall et al. 1982 and Carew et al. 1986).

Table 1: Least squares analysis of variance for average calving interval of N'Dama cows at the Fashola Stock Farm (1947 - 1977)

\begin{tabular}{lrc}
\hline Source & Df & Mean Square \\
\hline Year of birth & 30 & $29279.21^{* *}$ \\
Season of birth & 3 & 1746.97 \\
Parity of dam & 7 & $190297.06^{* *}$ \\
Regressions & & \\
Age of dam & 1 & $1255225.54^{* *}$ \\
Age at first calving & 1 & $907069.52^{* *}$ \\
Dam's inbreeding coefficient & 1 & 2686.73 \\
Error & 1226 & 7501.67 \\
\hline$* *=\mathbf{P}<\mathbf{0 . 0 1}, *=\mathbf{P}<\mathbf{0 . 0 5}$ & &
\end{tabular}

\section{Frequency distribution of calving intervals}

Only twelve percent of the cows studied had an average calving interval (CALINT) less or equal to 350 days (Figure 1), while 30.6 percent had CALINT between 350 and 400 days, 20.2 percent had CALINT between 400 and 450 days, 11.2 percent had CALINT between 450 and 500 days, 10.7 percent had CALINT between 500 and 550 days, 7.2 percent had CALINT between 550 and 600 days, 3.7 percent had CALINT 600 and 650 days, 2.3 percent had CALINT between 650 and 700 days while only 2.1 percent had CALINT above 700 days. The mean calving interval obtained in this study is close to 467 days reported by Touchberry
(1967) in Sierra Leone but lower than values obtained by Carew et al. (1986), Fall et al. (1982) and Olutogun (1976) in Teko, Sierra Leone, Kolda, Senegal and Upper Ogun, Nigeria respectively. These observed differences may be due to differences in the environment and management practices of the various research stations and farms. Although the calving rate obtained in this study is higher than values obtained by Tizikara (1988) for N'Dama cows at the Fashola Stock Farm, but this value is closer to those reported for N'Dama cows raised on research stations and tsetse free environments (ILCA, 1979; 1986). It would therefore appear that management is a key factor in calving interval in N'Dama. 


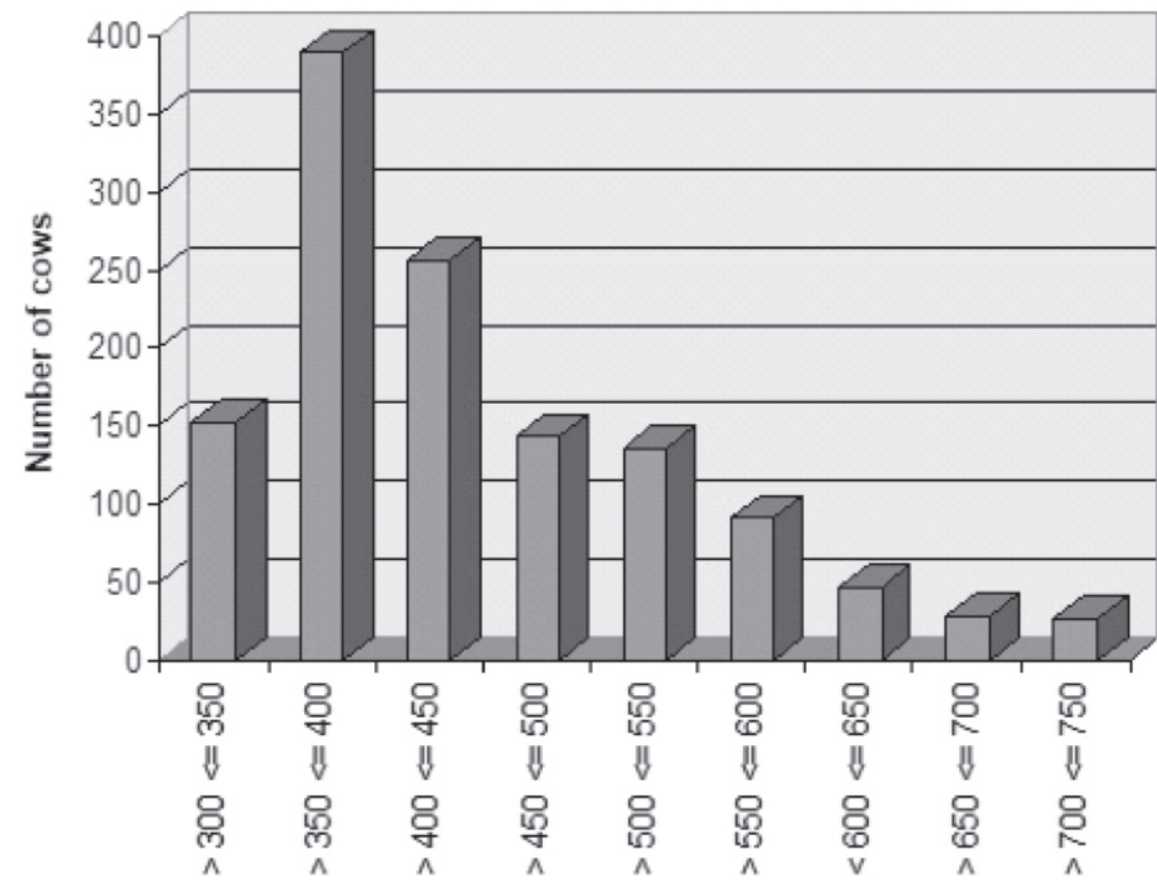

Calving Intervals (days)

Figure 1: Frequency distribution of N'Dama cows by average calving intervals at the Fashola Stock Farm (1947 - 1977).

\section{Year of birth}

The year of birth of cows exerted significant $(\mathrm{P}<0.05)$ influence on their average calving intervals (Table 2). The cows covered in this analysis are those born between 1947 and 1977. The least squares mean of average calving interval in this study was $367.57 \pm$ 9.85 days. The longest CALINT was recorded for cows born in 1977 (125.87 percent greater than the mean) while 1976 recorded the shortest CALINT (35.98 percent less than the mean). The frequency distribution of the cows used in this analysis follows the same pattern as in the calving distribution discussed earlier. The preindependence era had more cows than the post-independence era. Cows born between 1947 and 1959 (13 years) accounted for 89.92 percent of the total cows used in this analysis while those born between 1960 and 1977 (18 years) accounted for only 10.08 percent of the total cows used. This may be adduced for the very high standard errors obtained for CALINT in the post-independent era.

The average calving interval obtained in the pre-independent era are relatively more consistent and reliable than those of the post-independent era and also the values obtained are not significantly different throughout this period (1947 - 1959).

This observation can only be explained in terms of the frequency distribution across the years and the associated changing management policies of the farm. Thus, calving interval in N'Dama cattle is more affected by environmental rather than genetic factors as reported by various workers (Akinokun, 1970; Olutogun, 1976; Mrode, 1984; Wilson, 1986; Tizikara, 1988 and Ojo, 1991). 
Abanikannda and Olutogun

Table 2: Effect of year of birth of N'Dama cows on average calving interval (days) at the Fashola Stock Farm (1947 - 1977)

\begin{tabular}{|c|c|c|c|}
\hline Year of Birth & $\mathbf{N}$ & LS Mean (Days) & S.E. \\
\hline 1947 & 382 & $388.94^{\mathrm{bc}}$ & 9.61 \\
\hline 1948 & 11 & $355.89^{\text {bcde }}$ & 31.09 \\
\hline 1949 & 63 & $354.40^{\text {bcde }}$ & 12.96 \\
\hline 1950 & 81 & $357.62^{\text {bcde }}$ & 11.55 \\
\hline 1951 & 82 & $384.12^{\mathrm{bc}}$ & 11.86 \\
\hline 1951 & 67 & $362.72^{\mathrm{bcd}}$ & 13.21 \\
\hline 1953 & 56 & $381.73^{b c}$ & 13.68 \\
\hline 1954 & 66 & $355.46^{\text {bcde }}$ & 12.94 \\
\hline 1955 & 69 & $339.17^{\text {bcde }}$ & 12.02 \\
\hline 1956 & 63 & $361.18^{\mathrm{bcd}}$ & 12.51 \\
\hline 1957 & 76 & $379.03^{b c}$ & 12.26 \\
\hline 1958 & 79 & $374.17^{\mathrm{bcd}}$ & 12.35 \\
\hline 1959 & 47 & $380.34^{b c}$ & 14.77 \\
\hline 1960 & 15 & $277.67^{\mathrm{cde}}$ & 25.52 \\
\hline 1961 & 7 & $352.34^{\text {bcde }}$ & 37.10 \\
\hline 1962 & 3 & $325.76^{\text {bcde }}$ & 51.70 \\
\hline 1963 & 7 & $331.86^{\text {bcde }}$ & 35.14 \\
\hline 1964 & 11 & $307.57^{\mathrm{cde}}$ & 29.10 \\
\hline 1965 & 4 & $361.54^{\mathrm{bcd}}$ & 45.18 \\
\hline 1966 & 4 & $358.63^{\text {bcde }}$ & 44.76 \\
\hline 1967 & 8 & $368.47^{\mathrm{bcd}}$ & 32.56 \\
\hline 1968 & 4 & $337.59^{\text {bcde }}$ & 43.83 \\
\hline 1969 & 1 & $336.74^{\text {bcde }}$ & 87.34 \\
\hline 1970 & 2 & $251.09^{\mathrm{de}}$ & 62.07 \\
\hline 1971 & 22 & $438.04^{b}$ & 20.56 \\
\hline 1972 & 13 & $398.42^{b c}$ & 25.05 \\
\hline 1973 & 6 & $385.86^{\mathrm{bc}}$ & 36.26 \\
\hline 1974 & 10 & $351.24^{\text {bcde }}$ & 28.61 \\
\hline 1975 & 8 & $371.65^{\text {bcd }}$ & 31.83 \\
\hline 1976 & 1 & $235.31^{\mathrm{e}}$ & 87.09 \\
\hline 1977 & 2 & $830.24^{a}$ & 65.12 \\
\hline
\end{tabular}

Means with different superscripts differ significantly $(\mathrm{P}<0.05)$

\section{Season of birth}

Season of birth did not exert any notable effect on CALINT of N'Dama cows studied. Table 3 shows the least squares mean of calving interval by season of birth of cows. The large differences observed in the frequency distribution of the cows by the season of birth may be adduced for the insignificance of season on CALINT. 45.83 percent of the cows were born in the late dry season, while 18.74 percent were born in the early wet season, 14.72 percent in the late wet season and 20.71 percent in the early dry season. This distribution is not as uniform as would be expected since the late dry season accounted for almost half of the total cows studied. Although Tizikara (1988) reported significant effect of season 


\section{Influence of inbreeding on calving intervals of N'Dama cattle}

Table 3: Seasonal effects on average calving interval (Days) of N'Dama cows at the Fashola Stock Farm (1947 - 1977).

\begin{tabular}{lccc}
\hline \multicolumn{1}{c}{ Season } & N & L.S. Means (Days) & S.E. \\
\hline Late dry (Jan-Mar) & 582 & 370.73 & 11.12 \\
Early wet (Apr-Jun) & 238 & 368.08 & 11.20 \\
Late wet (Jul-Sep) & 187 & 363.18 & 11.65 \\
Early dry (Oct-Dec) & 263 & 368.31 & 10.86 \\
\hline
\end{tabular}

\section{Dam parity}

The parity of dam exerted significant influence on CALINT of N'Dama cows. Table 4 depicts the parity effect on average calving interval of N'Dama cows. The frequency distribution of cows consistently decreases with increasing parity number. Cows with only two parities accounted for 34.33 percent of the total cows used in this analysis, while cows with nine parities accounted for only 1.42 percent of the total cows studied. This constant decrease in frequency as a result of increasing parity number is expected and confirms the observation of Tizikara (1988) and Olutogun (1976). First calving interval of cows (parity two) is 43.70 percent longer than the mean calving interval of the cows. Second calving interval (parity three) is 23.20 percent longer, while third calving interval (parity four) is 9.42 percent longer than the mean calving interval. The ninth parity (eight calving interval) recorded the shortest interval (35.54 percent shorter than the mean calving interval). The calving intervals are meaningfully different from one another.

The implication of this observation is that primiparous animals take more time to conceive after parturition and this is as a result of the delay in the oestrus of the cow. The hormonal changes occurring in the animal at parturition needs some time to restore the animal back to its initial physiological state and thus this lapse of time decreases with increasing parities. This means that the higher the parities the shorter the lapse of time for restoring hormonal balance and therefore the shorter the calving interval (Tizikara, 1988; Olutogun, 1976 and Akinokun, 1970).

\section{Age of dam}

Increasing parity of dam indirectly means increasing age of dam. It is then anticipated that age of dam should exert similar influence on CALINT. The age of dam significantly $(\mathrm{P}<0.01)$ affected the CALINT of N'Dama cows. The average age of dam (DAMAGE) used in this analysis was $82.69 \pm 1.02$ months. The age at which the cow first calved also exert significant $(\mathrm{P}<0.01)$ influence on the CALINT of cows. The average age at first calving (AFC) of the cows used in this analysis was $40.84 \pm 0.84$ months. The correlation between DAMAGE and AFC was 0.59 , while the correlation between DAMAGE and CALINT was 0.10 and correlation between AFC and CALINT was -0.0093 . The regression of DAMAGE on CALINT was $0.423 \pm 0.091$ days and AFC on CALINT was $-0.334 \pm 0.110$ days. This implies that a month increase in DAMAGE will lead to a corresponding 0.423 days increase in CALINT while a unit increase in AFC will lead to 0.334 days decrease in CALINT. This means that the older the animal at first calving the shorter its calving intervals but the older an animal grows the longer its calving interval. Although the correlation between these traits is very low, yet the regressions are statistically significant $(\mathrm{P}<0.01)$.

\section{Level of inbreeding}

Inbreeding level of cows did not exert significant effect on the calving intervals of 
Abanikannda and Olutogun

Table 4: Effect of parity on average calving interval of N'Dama cows at the Fashola Stock Farm (1947 - 1977)

\begin{tabular}{cccc}
\hline Parity & N & L.S. Means (Days) & \multicolumn{1}{c}{ S.E. } \\
\hline 2 & 436 & $528.34^{\mathrm{a}}$ & 10.19 \\
3 & 276 & $452.85^{\mathrm{b}}$ & 9.02 \\
4 & 195 & $402.19^{\mathrm{c}}$ & 9.66 \\
5 & 142 & $370.98^{\mathrm{d}}$ & 11.24 \\
6 & 95 & $360.38^{\mathrm{e}}$ & 13.73 \\
7 & 71 & $313.80^{\mathrm{f}}$ & 16.83 \\
8 & 37 & $275.11^{\mathrm{g}}$ & 21.23 \\
9 & 18 & $236.95^{\mathrm{h}}$ & 27.04 \\
\hline
\end{tabular}

Means with different superscripts differ significantly $(\mathbf{P}<0.05)$

cows studied. The mean inbreeding coefficient of cows (DAMINB) used in this analysis was 0.098 percent, and the correlation between DAMINB and CALINT was -0.0219 . The regression of DAMINB on CALINT was $-1.096 \pm 2.11$ days. The relatively high standard error of DAMINB may be due to the very low number of inbred cows included in this analysis and the consequently low mean DAMINB for the analysis. This may probably be the reason for the insignificance of the regression of DAMINB on CALINT. Although this observation agrees with Srinivas and Gurnani (1981) but most workers reported that inbreeding of dam had important influence on their calving intervals (Alexander and Bogart, 1961; Swiger et al, 1961; Flower et al, 1963; Dinkel et al. 1972; Hudson et al, 1984; McCurley et al. 1984; Maksimova and Brovko, 1985; Smith et al. 1998; Cassell, 2007; Mc Parland et al. 2007; Reis Filho et al. 2015; Nazokkarmaher, 2016 and Musingi et al. 2018).

\section{Conclusion}

Most of the factors affecting calving interval of N'Dama cattle at the Fashola Stock Farm are essentially environmental in nature rather than genetic. Inbreeding of the dams did not exert any significant influence on their subsequent calvings and this implies that although the animals have innate capabilities to perform better, the environment is however inimical to the maximum realization of this potential.

\section{References}

Abanikannda, O. T. F. 1995. Computer based pedigree charting and inbreeding effects on performance traits of N'Dama cattle in Fashola, Oyo State, Nigeria. Ph.D. thesis, Dept. of Animal Science, University of Ibadan, Nigeria. Pp. 205.

Akinokun, O. 1970. A preliminary study of age at first calving and calving intervals of a herd of N'Dama cattle. Nig. Agr. J. 7: 148 - 151.

Alexander, G. I. and Bogart, R. 1961. Effect of inbreeding and selection on performance characteristics of beef cattle. J. Anim. Sci. 20(4): 702 - 707.

Baird, J. D., Maxie, M. G., Kennedy, B. W. and Harris, D. J. 1986. D i lated (c o nge s t i v e ) cardiomyopathy in Holstein cattle in Canada; genetic analysis of 25 cases. Proceedings of the 14th World Congress on Diseases of Cattle, Dublin. 1,89-94.

Brinks, J. S. and Knapp, B. W. 1975. 


\section{Influence of inbreeding on calving intervals of N'Dama cattle}

Effects of inbreeding on performance traits of beef cattle in the Western region. Colorado State University Tech. Bull. 123: 1 $-36$.

Carew, S. F., Sanford, J., Wissocq, Y. J., Durkin, J. and Trail, J. C. M. 1986. N'Dama cattle productivity at Teko livestock station, Sierra Leone and initial results from crossbreeding with Sahiwal. ILCABulletin No. 23: 2 - 11.

Cassell, B. G. 1999. Effect of Inbreeding on Lifetime Performance of Dairy Cows. Advances in Dairy Technology. 11: 13-23.

Cole, W. J., Bierschwal, C. J., Youngquist, R. S. and Braun, W. F. 1986. Cystic ovarian disease in a herd of Holstein cows: a hereditary correlation. Theriogenology 25: (6) 813 - 820.

Dbase IV 1990. Database Management system. (Version 4.0). Ashton Tate Corp. U.S.A.

Dhillon, B. S. and Khehra, A. S. 1984. Suggestions to overcome the limitation of inbreeding in modified full - sib selection. Cereal Research Communications. 12: $(1 / 2) 105-106$.

Dinkel, C. A., Anderson, L. M., Parker, W. R. and Trevillyan, W. R. 1972. Effects of inbreeding on fertility and livability in beef cattle. $J$. Anim Sci. 35 (4): 725 - 729.

Falconer, D. S. 1993. Introduction to quantitative genetics. Oliver and Boyd, Edinburgh. (4th Edition).

Fall, A., Diop, M., Sanford, J., Wissocq, Y. J., Durkin, J. and Trail, J. C. M. 1982. Evaluation of the productivities of Djallonke sheep and N'Dama cattle at the Centre de Recherches Zootechniques, Kolda, Senegal. ILCA Research
Report No. 3.Pp 70.

FAO 1980. Trypanotolerant livestock in West and Central Africa. Vol. 2. Country studies. Rome, Animal production and health paper No. 20 (In collaboration with ILCA and UNEP).

Fisher, R. A. 1965. The theory of inbreeding. Oliver and Boyd, Edinburgh (2nd Edition) Pp 150.

Flade, D. and Zeller, K. 1986. Effect of moderate inbreeding on inbreeding rate, culling rate, reasons for culling, body weight gain and semen production and quality of young bulls. Wissenchaftliche Zeitschrift der Humboldt Universitat $\mathrm{zu}$ Berlin, Mathematisch Naturwissen chaftliche Reihe. 35: 4, 327 - 334.

Flower, A. E., Brinks, J. S., Urick, J. J. and Willson, F. S. 1963. Comparisons of inbred lines and linecrosses for performance traits in Hereford range cattle. J. Anim. Sci. 22(4): 914 - 918.

Guba, S. and Wolf, G. 1984. Changes in some standard characteristics of cattle in response to various extents of inbreeding. Acta Agronomica Academiae Scientiarum Hungaricae. 33: 1-2,67-95.

Harvey, W. R. 1989. User's Guide for LSMLMW PC-1 version. Mixed model least squares and maximum likelihood computer program. Dept. of Dairy Sc., Ohio State University, U.S.A. Pp 59.

Havrankova, J., Slavickova, M., Cerny, M. and Slapnicka, J. 1984. Achondroplasia in the progeny of bulls from one line - a cytogenetic e $x$ a mination of sires. Veterinarstvi. 34: 3, 128 - 130.

Hohenboken, W. D. 1985. The manipulation of variation in 


\section{Abanikannda and Olutogun}

quantitative traits: a review of possible genetic strategies. $J$. Anim. Sci. 60: 1, 105 - 110.

Hudson, G. F. S., Vleck, L. D. van and Van-Vleck, L. D. 1984. Effects of inbreeding on milk and fat production, stayability and calving interval of registered Ayshire cattle in the Northeastern United States. J. Dairy Science. 67: 1, 171 - 179.

ILCA 1979. Trypanotolerant livestock in West and Central Africa. Vol. 1. General study, Addis Ababa, ILCA Monograph No. 1/2 Pp 148.

ILCA 1986. Trypanotolerance network situation report, December 1985. ILCA Livestock Productivity and Trypanotolerance Group. Working Document 222, 98p.

Kravchenko, N. A., Vinnichuk, D. T., Gavrilenko, V. P. and Pavlovskii, G. A. 1985. Selection and genetic parameters in record-yielding inbred or outbred Simmental cows. Molochno Myasnoe Skotovodstvo, Kiev. 67, 35 - 37.

MacNeil, M. D., Dearborn, D. D., Cundiff, L. V., Dinkel, C. A. and Gregory, K. E. 1989. Effects of inbreeding and heterosis in Hereford females on fertility, calf survival and preweaning growth. J. Anim. Sci. 67: 895 - 901.

Maksimova, T. M. and Brovko, N. V. 1985. Type of breeding and reproductive performance of cows. Sbornik Trudov. Belorusskii Hauchno Issledovatel'skii Institut Zhivotnovodstva. 26, 57-61.

Malécot, G. 1969. The mathematics of heredity. W.H. Freeman and Co., San Francisco. Pp 88.

McCurley, J. R., Butts, W. T. and Bovard, K. P. 1984. Growth patterns of Angus, Hereford and Shorthorn cattle. I. Comparison of inbred and non-inbred lines, changes in patterns over time and effects of level of inbreeding and reproductive performance. $J$. Anim. Sci. 59: 5, 1194 - 1204.

McDowell, R. E. 1983. Strategy for improving beef and dairy cattle in the tropics. Cornell International Agriculture Mimeograph. No. 100, $34 \mathrm{pp}$.

Mc Parland, S., Kearney, J. F., Rath, M. and Berry, D. P. 2007. Inbreeding Effects on Milk Production, Calving Performance, Fertility and Confirmation in Irish HolsteinFriesians. J. Dairy Sci. 90:44114419.

Mrode, R.A. 1984. A study of body weight and reproductive performance in White Fulani cattle. M. Phil. thesis, Dept. of Anim. Sci. University of Ife, Nigeria. 126p.

Musingi, M., Muasya, T. K., Ilatsia, E. D. and Kahi, A. K. 2018. Effect of inbreeding on traits of economic importance in Kenyan Sahiwal cattle. Livestock Research for Rural Development. Volume 30, Article \#13. Retrieved August 19, 2019, from

Nazokkarmaher, M. 2016. The effect of inbreeding on Holstein-Friesian breed. All Graduate Plan B and o the r R e ports . 864 . https://digitalcommons.usu.edu/gr adreports/864

Noland, P. R., Gifford, W. and Brown, C. J. 1964. Effects of inbreeding in a Poland China line of Swine on certain productivity traits. Arkansas Agr. Expt. Sta. Tech. Bull. Pp 23.

Ojo, F. O. 1991. Correlations between heifers' weight and age at first calving of N'Dama cattle at 


\section{Influence of inbreeding on calving intervals of N'Dama cattle}

Fashola Stock Farm. B.Sc. Project. Dept. of Anim. Sci. University of Ibadan, Nigeria. 49p.

Olutogun, O. 1976. Reproductive performance and growth of N'Dama and Keteku cattle under ranching conditions in the Guinea savannah of Nigeria. Ph.D. Thesis. University of Ibadan, Nigeria. Pp 292.

Reis Filho, J. C., Verneque, R., Torres, R., Lopes, P. S., Raidan, F. S. and Toral, F. 2015. Inbreeding on productive and reproductive traits of dairy Gyr cattle. Revista Brasileira de Zootecnia, 44(5), $\begin{array}{lllllll}1 & 7 & 4 & - & 1 & 7 & 9\end{array}$. https://dx.doi.org/10.1590/S1806$\underline{92902015000500002}$

Russell, W. C., Brinks, J. S. and Richardson, G. V. 1984. Changes in genetic variances with increased inbreeding of beef cattle. Journal of Heredity. 75: 1, 8 - 10.

SAS 1999. SAS Users guide: Statistics, Statistical analysis systems Inc. Cary, North Carolina, U.S.A. Pp 584.

Sachdeva, G. K., Tomar, S. S. and Sharma, A. 1983. Effects of inbreeding on various economic traits of dairy cattle - a review. Agricultural Reviews 4: 2, 136 142.

Smith, L. A., Cassell, B. G. and Pearson, R. E. 1998. The Effects of Inbreeding on the Lifetime Performance of Dairy Cattle. $J$. Dairy Sci. 81:2729-2737.

Sorensen, D. A. and Kennedy, B. W. 1984. Estimation of genetic variances from unselected and selected populations. J. Anim. Sci. 59: 5, $1213-1223$

Srinivas, B. and Gurnani, M. 1981. Incidence of inbreeding and its effect on some traits of Sahiwal cattle. Indian Journal of Dairy Science. 34: 1, 8-15.

Swiger, L. A., Gregory, K. E., Koch, R. M. and Arthaud, V.A. 1961. Effect of inbreeding on performance traits of beef cattle. J. Anim. Sci. 20(3): $626-630$.

Tizikara, C. 1988. Estimation of genetic parameters of some growth and reproductive traits in N'Dama cattle and their crosses. Ph.D. Thesis, Dept. of Animal Science, Obafemi Awolowo University, Ile - Ife, Nigeria. Pp 160.

Touchberry, R. W. 1967. A study of N'Dama cattle in the Musaia animal husbandry station in Sierra Leone. Univ. of Illinois Agr. Exp. Sta. Bull. No. 724, 40p.

Wilson, R. T. 1986. Livestock production in central Mali: Long term studies on cattle and small ruminants in the agropastoral system. ILCA Research Report No. 14, 111p.

Woolliams, C., Wiener, G. and Macleod, N. S. M. 1983. The effects of breed, breeding system and other factors on lamb mortality. 3 . Factors influencing the incidence of weakly lambs as a cause of death. Journal of Agricultural Science, U.K. 100: 3, 563 - 570.

Wright, S. 1921. Systems of mating. I - V. Genetics 6: 111 - 178.

Wright, S. 1922. Coefficients of inbreeding and relationship. Am. Nat. 56: 330 - 339.

Received: $30^{\text {th }}$ June, 2019

Accepted: $21^{\text {st }}$ August, 2019 